\title{
STUDENT LEADERSHIP AND DEVELOPMENT: A PANORAMIC VIEW OF TRENDS AND POSSIBILITIES
}

The millennium age of educational leadership opens a new perspective towards student leadership (Black et al., 2014). The idea of student leadership in the $21^{\text {st }}$ century has risen (Adams \& Velarde, 2018), the call for student leadership gaining in momentum, as various enhanced leadership models and trends are developed for students (Tan \& Adams 2018; Tie, 2012). Scholars argue that students' leadership development should be a priority to assist students to form a strong leadership identity at an early stage (Adams, Kamarudin, \& Tan, 2018; Amirianzadeh, 2012; Keselman et al., 2015; Simonsen et al., 2014; Villarreal et al., 2018).

There are still lingering doubts over the leadership competencies of student leaders. As leaders of tomorrow; it is imperative they grasp an understanding of the many leadership styles, know the leadership models and exposed to leadership development programs that enables them to increase their knowledge, competence, skills and capabilities as leaders. Student leadership development is now the responsibility of all members of the learning community (Dugan \& Komives, 2007) and schools have a responsibility to prepare students to lead (Adams, Kamarudin, \& Tan, 2018). However, there is little research regarding student leadership and leadership development models (Wisner, 2011).

Astin's (1977) decades of research on student leadership may have sparked initial discussions. Astin's introduction of the Student Involvement Theory and subsequently developing three important models of student leadership; namely the College Impact Model, the Social Change Model, and the Transformative Leadership Model serves as a guide for other research on understanding student qualities and characteristics and the nature of the educational environment students experience (Astin, 1991), students' leadership development (Astin et al., 1996), and to transform a campus to a leadership environment (Astin \& Astin, 2000).

Subsequently, the Student Leadership Challenge Model was developed by Kouzes and Posner (2003) highlighting common practices of exemplary student leadership and how they influence others "a desire to make something happen, to change the way things are, to create something that no one has ever created before" (p. 15). Amirianzadeh, Jaafari, Ghourchian and Jowkar (2010) combined both Astin's et al (1996) and Kouzes and Posner (2003) work to develop the Student Leadership Competencies Model. The model looks at the effects of students' involvement, environment, attitudes and behaviour as important variables in student leadership competencies development.

A more contemporary theory of student leadership emerged in Amirianzadeh's (2012) Hexagon Theory of Student Leadership. This theory was built upon empirical student leadership research over the past two decades. The theory advocates that student leadership develops from education, training and development through the individual himself and their social environment, thus this model enables the students to function within these dimensions as a leader. Interestingly, Bolman and Deal's (1997) Four-Frame 
Model, one of the best-known theories of leadership and management (Bush, 2011) remains relatively unexplored in the area of student leadership (Tan \& Adams, 2018).

A notable observation is that most student leadership literature comes from the researchers' perspective rather the student's perspective (Dempster \& Lizzio, 2007). While it's important to understand the various models of student leadership as the development of leadership training and development programmes will enhance' students' leadership effectiveness (Adams, 2018; Wisner, 2011), the true voices of the students are outweighed by the voices of researchers (Aminitehrani, 2017). This has become all the more apparent especially among students with disability where research on student leadership among students with disability is yet to be uncovered worldwide (Chapman, Ainscow, Miles, \& West, 2011).

While researchers come up with various models of student leadership and educators wax eloquently about the importance of developing student leaders, these remain theories until they are applied practically in leadership development programmes for students. There is a need for more research on student leadership, factors that inhibit its effectiveness and the challenges encountered, in order to develop leadership programs for students to have the added competencies that the 21st century demands.

\section{REFERENCES}

Adams, D. (2018). Mastering Theories of Educational Leadership and Management. Kuala Lumpur: University of Malaya Press.

Adams, D. \& Velarde, J. (2018). Leadership and Management in Education: Role and Influence. In D. Adams (Ed.), Mastering Theories of Educational Leadership and Management. Kuala Lumpur: University of Malaya Press.

Adams, D., Kamarudin, F. \& Tan, M.H.J. (2018). Student Leadership: Development and Effectiveness. In D. Adams (Ed.), Mastering Theories of Educational Leadership and Management. Kuala Lumpur: University of Malaya Press.

Aminitehrani, B. (2017). Am I a leader? Understanding leadership from high school students in leadership positions. (Doctoral dissertation), California State University.

Amirianzadeh, M. (2012). Hexagon theory - student leadership development. Procedia Social and Behavioral Sciences, 31(11), 333-339.

Amirianzadeh, M., Jaafari, P., Ghourchian, N., \& Jowkar, B. (2010). College Student Leadership Competencies Development: A Model. International Journal for CrossDisciplinary Subjects in Education, 1(3), 168-172.

Astin, A.W. (1977) Four critical years. San Francisco: Jossey-Bass

Astin, A.W. (1991) Assessment for excellence. New York: Macmillan.

Astin, A., Astin, H., Boatsman, K., Bonous-Hammarth, M., Chambers, T., Goldberg, S., et al. (1996) A social change model of leadership development: Guidebook (Version III). Los Angeles: University of California, Higher Education Research Institute.

Astin, A. W. \& Astin, H. S. (2000) Leadership reconsidered: Engaging higher education in social change. Battle Creek, MI: W.K. Kellog Foundation.

Black, R., Walsh, L., Magee, J., Hutchins, L., Berman, N., and Groundwater-Smith, S. (2014). Student Leadership: A Review of Effective Practice. Canberra: ARACY.

Bolman, L. G. \& Deal, T. E. (1997) Reframing organisations: Artistry, choice, and leadership (2nd ed.). San Francisco: Jossey-Bass. 
Bush, T. (2011) Theories of Educational Leadership and Management (4th ed.). London: Sage.

Chapman, C., Ainscow, M., Miles, S., \& West, M. (2011). Leadership that promotes the achievement of students with special educational needs and disabilities. Nottingham, UK: National College for School Leadership.

Dempster, N., \& Lizzio, A. (2007). Student leadership: Necessary research. The Australian Journal of Education, 51(3), 276-285.

Dugan, J. P., \& Komives, S. R. (2010). Influences on college students' capacities for socially responsible leadership. Journal of College Student Development, 51(5), 525-549.

Keselman, A., Ahmed, E. A., Williamson, D. C., Kelly, J. E., \& Dutcher, G. A. (2015). Harnessing health information to foster disadvantaged teens' community engagement, leadership skills, and career plans: A qualitative evaluation of the Teen Health Leadership Program. Journal of the Medical Library Association, 103(2), 82-86.

Kouzes, J.M., \& Posner, B.Z. (2003). The student leadership practices inventory. San Francisco: Jossey-Bass.

Simonsen, J. C., Velez, J. J., Foor, R. M., Birkenholz, R. J., Foster, D. D., Wolf, K. J., \& Epps, R. B. (2014). A multi-institutional examination of the relationships between high school activity involvement and leadership characteristics. Journal of Agricultural Education, 55(1), 200-2014.

Tan, M. H., \& Adams, D. (2018). Malaysian student leaders' perception of their leadership styles. International Journal of Innovation and Learning, 23(3), 368-382.

Tie, F. H. (2012). Leadership for Learning in Malaysian Schools. In MacBeath, J., \& Townsend, T. (eds.), International Handbook of Leadership for Learning. Dordrecht: Springer.

Villarreal, S., Montoya, J. A., Duncan, P., \& Gergen, E. (2018). Leadership styles predict career readiness in early college high-school students. Psychology in the Schools, 55(5), 476-489. Doi:10.1002/pits.22131.

Wisner, M. D. (2011). Psychological strengths as predictors of effective student leadership. Christian Higher Education, 10(3-4), 353-375.

Donnie Adams

Editor of International Online Journal of Educational Leadership Institute of Educational Leadership, Faculty of Education, University of Malaya donnieadams@um.edu.my

and Pavithra Semaadderi and Tan King Lok Institute of Educational Leadership, Faculty of Education, University of Malaya 